\title{
Circular Migration and Precarity: Perspectives from Rural Bihar
}

\author{
Amrita Datta ${ }^{1,2}$
}

Accepted: 21 September 2020 / Published online: 12 November 2020

(c) Indian Society of Labour Economics 2020

\begin{abstract}
Migration and mobilities are vastly underestimated in India. In particular, circular migration remains poorly captured as circular migrants move back and forth between source and destination regions. Based on survey data from rural Bihar, an important source region of migration in India, this paper finds that a vast majority of migrants work and live in precarity in predominantly urban and prosperous destinations across India. However, those at the lowest rungs of the social and economic ladder in source regions - the scheduled castes and scheduled tribes, other backward classes I and the labouring class - are the worst off at destination; they are part of the most precarious shorter-term migration streams, earn the lowest incomes, have the poorest conditions of work, and live in the harshest circumstances. The paper shows that social and economic hierarchies, and in turn, precarity in source region is reproduced at destination, and, thus, there is little evidence that spatial mobility is associated with social mobility. Focusing on migrants' location, work, employment, income, housing, and access to basic services at destination, the paper foregrounds migrant precarity and adds to a small body of empirical literature that is significant in understanding the spatial and structural elements of circular migration in India and in turn, the migration crisis that emerged as a result of the economic shock of the COVID 19 pandemic.
\end{abstract}

Keywords Circular migration · Labour migration - Rural-urban migration · Bihar . India $\cdot$ COVID 19

Amrita Datta

amritadatta@la.iith.ac.in

1 Department of Liberal Arts, Indian Institute of Technology Hyderabad, Sangareddy, Telengana, India

2 Institute for Human Development, New Delhi, India 


\section{Introduction}

The stringent lockdown imposed in India on March 242020 resulted in informal migrant workers across the country losing their jobs, incomes, and becoming stranded in distressing conditions, in destinations far away from their homes (SWAN 2020). The subsequent pictures of these migrants-of men, women, and children-determinedly walking hundreds of kilometres were hauntingly reminiscent of images from the Partition of 1947, the largest mass migration in history of the Indian subcontinent.

How do we make sense of this crisis of migration-the mass exodus of workers from India's cities? Why did migrant workers defy the national lockdown to undertake arduous journeys 'home'? An analysis of the nature and pattern of this migration can shed some light to these questions. This paper, based on a primary study, focuses on migration from rural Bihar, an important source region of longdistance labour migration in the country. The spatial and structural elements of this migration stream, emphasised in the paper, are important in a context where migration from Bihar is known to be significant, but remains underestimated and understudied, with little being known about its magnitude, patterns, and processes.

Migrants are part of India's invisible workforce. One of the reasons they remain invisible, particularly to policymakers, is that there are no accurate estimates of the extent of migration in India. This is also, one of the reasons, why literally noone in the corridors of power anticipated the migration crisis that ensued from the lockdown. The two main data sources of migration in India-the National Sample Survey Office and the Census - underestimate the extent of migration in India as they are biased towards long-term migration and unable to properly capture short-term, seasonal, and circular streams. The Census is primarily designed to capture the distribution of population, and the NSSO focuses on labour market attributes. As a result, worker mobility is not a primary area of enquiry for either agency, both of which define migration differently. The Census uses the criteria of change in place of birth and 'a change in the usual place of residence... with reference to his/ her previous usual residence' (Census of India 2001). According to the NSS, 'a household member whose last usual place of residence (UPR) was different from the present place of enumeration was considered as a migrant member in a household', the UPR of a person being the place where the person had stayed continuously for a period of six months or more (GOI 2010, p. 11). It is pertinent to note that the Census does not collect data on temporary and shortterm migration, and the NSS uses a cut-off point of 6 months to define short-term migration. This may not adequately capture circular movements which are longer than six months.

It is against the aforementioned policy context of underestimation and in turn, invisibility of migration, that this paper presents patterns of migration from rural Bihar, with an emphasis on precarity of migrant workers. The paper is organised as follows: Section 2 reviews select literature to discuss the embeddedness of circular migration in capitalist development in contemporary India, the role 
of the household, and the particular contexts of source and destination regions. It then unpacks the concept of circular migration, using empirical studies from the Global South and India. Section 3 details the data and methods used in the study. Section 4 presents key characteristics of migration from rural Bihar from the primary study, emphasising on who migrates from the source region, and Sect. 5 focuses on migrant workers' location, work, employment, income, and other attributes at destination to show and how precarity is reproduced in destination regions. In view of the findings from the primary study, Sect. 6 concludes, with policy implications that may help better understand the current migration crisis.

\section{Select Review of Literature}

The immediate crisis of migration - the exodus of migrant workers-stems from a deeper, structural crisis of migration in India. This can be seen from a Marxist analytical framework where processes of capitalist accumulation have led to surplus extraction and super-exploitation of labour (Jain and Sharma 2019; Lerche and Shah 2018). Migration, crucial for capitalist growth and labour mobility, far from being voluntary, is viewed as a compulsion generated in the interest of capital (Shah and Lerche 2020; Vijay 2005). Increasing circular mobility and informalisation of the workforce are closely intertwined; circular migration facilitates the informalisation of economic activity; at the same time, the informal economy puts a premium on labour mobility' (Breman 2019, p. 179). The growing number of seasonal and circular labour migrants is disproportionately from historically deprived scheduled caste and scheduled tribe communities (Srivastava 2019). Contemporary capitalism, thus, draws on labour market segmentation built on historical cleavages such as caste, class, gender, and religion to produce new forms of unfree labour and neo-bondage (Mander et al. 2019; Breman et al. 2009).

There is now a growing body of empirical literature that connects the dots between India's economic prosperity, with the precarity of its migrant workforce. In their study of the south Rajasthan-Gujarat migration corridor, Jain and Sharma (2019) demonstrate this precarity-prosperity nexus by showing that the exploitation of tribal migrant labour from Rajasthan leads to the creation of surplus value and concentration of wealth among the capitalist classes in Gujarat. In a similar vein, in the context of a new industrial town in south India, Vijay (2005) finds that migrant labour from agriculturally backward areas in poor states such as Bihar and Orissa are employed in the worst categories of employment, viz. daily contract and unregistered forms of employment at destination. Likewise, Shah and Lerche (2020) in their research in states with a high Human Development Index (Kerala, Tamil Nadu, and Himachal Pradesh) find that the cheapest and most exploited workforce in these prosperous destination regions is drawn from seasonal low caste and tribal migrants belonging to the poorest and most backward regions. In particular, the construction sector, notorious for its poor working conditions and low wages, is dominated by seasonal Dalit and Adivasi migrants. Destination-area surveys of construction workers show that long-distance circular migrants form the bulk of this workforce (Parida et al. 2020; Srivastava and Jha 2016). Overall, this literature suggests that 
economic prosperity in destination regions, thus, is contingent upon the exploitation of a highly mobile and circular migrant workforce from poor-source regions. These spatial patterns of precarity are also corroborated by official data of the National Sample Survey Office that shows that overall, nearly half of all short-duration outmigrants for employment are from the poorer states of Uttar Pradesh and Bihar (Srivastava 2020).

The household, as an institution, plays a critical role in enabling and sustaining the mobilities of circular migrants. In the livelihoods literature, circular migration is viewed as a rural household strategy where some members migrate for work while others stay put in the village (World Bank 2007; Ellis 1998). This leads to multi-sited households where members are spread between source and destination areas to maximise income and diversify risks (Stark and Lucas 1988). In the context of this paper, foregrounding the multi-sited household sheds light on its spatial structures, where high individual mobility of circular migrants is located within a geographically fixed, immobile household in the source region. Household arrangements of work and care are structured by the dynamics between this immobile household and its mobile individual members. Mobility allows circular migrants to bring remittances to the household, and, in turn, their migrations are sustained by the 'invisible economies of care' - productive and reproductive work undertaken by kin of migrant workers in source regions (Shah and Lerche 2020, p. 3). That circular migrants spend much of their working lives away from the village and return to retire suggests that the rural household, and rural areas, bear the cost of production and reproduction of this migrant labour force (Datta et al. 2014). Thus, the split, stretched, multi-sited rural household, is closely intertwined with the processes of capitalist exploitation of migrant labour in contemporary India.

The particular contexts of source and destination, the rural and the urban, are crucial to understand the crisis of migration under discussion. In the source regions, agriculture is characterised by low growth and a declining share in income and employment (Nadkarni 2018). Farming is increasingly considered economically unviable, and young people do not aspire to work in agriculture (Vijayabaskar et al. 2018). Workers from lower castes also prefer to work outside the village, away from the domination of upper castes (Roy, 2014; Sharma 2005). Furthermore, inadequate employment in the non-farm sector and the inability of public works programmes such as the Mahatma Gandhi National Rural Employment Guarantee Scheme to provide work have contributed to increasing outmigration for work from the rural areas (Sahu 2017; Datta 2016).

In destination areas, rural or urban, circular migrants remain at the margins of physical, social, cultural, and political spaces (Shah and Lerche 2020; Samaddar 2016). They work, predominantly in the informal sector, with low pay and negligible social security (Das and Sahu 2019; Hirway and Singh 2017). Their working and living conditions are precarious, and circular migrants experience acute social isolation and powerlessness in their work and life at destination (Datta 2018; Vijay 2005). This social exclusion is intertwined with their political exclusion; circular migrants are unable to participate in political processes in destination areas and tend to miss out on voting in elections in source regions (Mander et al. 2019). Thus, despite their economic contributions to source and destination regions, circular 
migrants, themselves, are rendered second-class citizens, and the state is complicit in the keeping them in a state of 'incomplete citizenship' (Jeyaranjan 2017, p. 325).

\subsection{Unpacking Circular Migration}

In the context of the Global South, circular migration has existed for long; empirical studies reveal complexity in its patterns and establish the importance of such migration, for instance, in the context of Southeast Asia (Hugo 1982; Rigg 2007a; Anh et al. 2012), China (Fan 2008; Murphy 2002), and Africa (Potts 2010; Collinson et al. 2006). In particular, they throw light on its changing patterns and point towards several methodological issues related to the study of circular migration. Some studies suggest the changing dynamics of circular migration; Potts (2010) in the context of South Africa finds that much of short-term circulation has been replaced by longer-term movement, but then again ending with a permanent move to a rural area. In the case of China, Chen and Fan (2018) suggest that over time, younger migrants increasingly have developed skills and strategies that allow them to stay for longer periods of time in the city.

It is also evident that circularity is strengthened in times of uncertainty and crisis. When urban areas cannot provide adequate employment or long-term security, circular migration is viewed as a rational response by rural-urban migrants. Peasant migrants are able to obtain the best of origin and destination by adopting a 'splithousehold strategy' which most frequently have involved husbands doing migrant work and wife staying on in the village (Fan 2008). This is also noted by Graeme Hugo in one of the earliest works on circular migration-'a circulation strategy keeps the mover's options in the village completely open so that the risk of not being able to earn subsistence is reduced by spreading it between village and city income opportunities' (Hugo 1982, p. 70).

There emerge several methodological challenges in the study of circularity in migration. First among these is that often circular and seasonal are understood to be one of the same thing, distinctly different from long-term migration. Conceptually, seasonal and circular migration are associated with short-term, irregular migration streams (for instance, see Rigg 2007b, p. 174). Even if there is consensus on the definition of circular migration, it is nearly impossible to estimate circular migrants in a context of high mobility, diverse livelihoods and multiple spatialities.

In the Indian context, there is small but significant and growing body of empirical literature on circular migration. Foremost among this is Jan Breman's seminal work on seasonal and temporary circular migration in south Gujarat that emphasises on 'footloose labour' or the 'footloose proletariat'-workers who possess little or no means of production and lead a circulatory existence in the lowest rungs of the labour system (Breman 1996). Footloose labour is pushed out of the agrarian labour market to depend on casual work, and their 'urban employment in the informal sector is marked by a cyclicality that is usually associated with agrarian-rural economic lifestyle' (Breman 1996, p. 70). Thus, migrant labour has remained footloose leading to their continual circulation rather than the permanent outmigration of workers from rural areas (Breman 2009). 
Breman's work, rooted in a Marxist framework, pivots towards a structural discourse on circular migration. Other studies have a more differentiated understanding of circular migration. Deshingkar and Farrington (2009) conceptualise circular migration in two categories: "coping migration", where households are able to smooth consumption and manage risk, and "accumulative migration" which allows accumulation of assets, savings, and investments (Deshingkar and Farrington 2009, p. 18). These migrations streams are not understood to be static, and it is argued that under favourable circumstances such as availability of more regular work and skill acquisition leading to better wages, coping migration streams may become accumulative. In a similar vein, in the context of western India, Mosse et al. (2002) find that labour migration, for some, is a forced livelihood response, while for others, it 'provides a positive opportunity to save, accumulate capital or invest in assets' (Mosse et al. 2002, p. 60). Even within highly precarious migration streams, it is found that migrants exercise their agency (Rogaly and Coppard 2003) to seek and obtain 'incremental and sometimes highly significant changes in microspaces of work and living, albeit it in a world dominated by capital' (Rogaly 2009, p. 1984).

Recent research has focused on the impact of circular migration on source regions and echo Rogaly (2009) and Rogaly and Coppard's (2003) findings. In the context of rural-urban migration to the Bangalore in south India, Pattenden (2012) finds unambiguous signs of upward socio-economic mobility among labouring class migrants in their villages despite their work in the urban construction sector being apparently rooted in poverty and exploitation. Pattenden argues that it is their labour circulation that makes it possible for migrants to become less dependent on the dominant classes for credit and employment. In another study in south India, Picherit (2012) views seasonal rural-urban migrants' aspirations to be centred around their lives in the village and argues that lower caste seasonal migrants mediate daily wage work in the construction sector to orchestrate their socio-political rise to seek gains in caste politics and development in their home villages. The critical common finding that emerges from both studies is that circular migration has enabled upward mobility for those at the lower rungs of the social and economic hierarchy in the village. These messages echo in more recent studies in western India that reveal that Dalits and Adivasi circular migrants take back with themselves not just skills in construction and savings, but also cultural icons of emancipation from the city to the village (Iyer 2017) and that seasonal labour migration has enhanced the ability of subaltern communities to assert themselves against landed farmers (Rai 2018).

The aforementioned studies draw on labour circulation, and what is common among these is that they associate circular migration with seasonal migration. Deshingkar and Farrington (2009) define circular migration as 'a temporary move from, followed by return to, the normal place of residence, for purpose of employment' (Deshingkar and Farrington 2009, p. 1). In standard surveys, the normal place of residence is where the respondent typically spends a majority of his or her time. Embedded in this definition is an understanding that the time spent away is less than time spent at the normal place of residence. However, the survey on which this paper is based shows that the most prevalent migration stream from rural Bihar in the areas studied is that of long-term labour circulation, where a majority of time spent by migrants is away from the village. 


\section{Data and Methods}

The data used in the paper are from a household survey and a migration module embedded therein, undertaken in 12 villages in 7 districts in rural Bihar in 2016 by the Institute for Human Development, New Delhi. These villages studied earlier-in 1981-1983, 1998-2000, and 2009-2011-were selected in 1981 from six regions of Bihar that were distinguished based on a cluster analysis. For selection of households in earlier surveys, stratified random sampling was undertaken and households were stratified by class (described below) and village (see Rodgers et al. 2016; Prasad et al. 19881988 for details). For the 2016 survey, an additional sampling frame was adopted for better representation of rural households. To this end, data from the publicly available Socio-Economic Caste Census (SECC) was used to classify households in each of the 12 villages in five occupational groups. Thereafter, the share of each occupational group was calculated for every village. At first, information was collected of the households of earlier surveys in 2009-2011, and these were classified into the aforementioned five broad groups. Subsequently, deficits in each SECC occupational group were covered by surveying new households in these groups. In this manner, a total of 1588 households were surveyed (see IHD 2018 for details).

For the purpose of this paper, first, we use data from the aforementioned 1588 households to present key characteristics of migration, viz. household-level migration by district, class, and landownership and individual-level migration by duration, sex, and activity status. The class-wise distribution of sample households is presented in Appendix Table 5. Second, given the predominance of migration for work, we used data from a specially designed migration module that collected detailed information, specifically related to current migrant workers' lives at destination, focusing on the location of migration, work undertaken at destination, income, employment contract, conditions of work, living conditions, housing and access to basic facilities, identity documents at source and destination, etc. As details of migration were sought in a source area survey, we were only able to capture information of a subset of all migrant workers. A total of 906 migrant workers were covered; the class-wise distribution of the sample of migrant workers can be found in Appendix Table 6.

The point of departure of this paper is that data collected on migration is from the source household. In the context of the source region, migration is a household livelihood strategy and permanent migration, i.e., migration that entails the relocation of the entire household is very low. ${ }^{1}$ Within this context, in the survey, the working definition of a household is a person or a group of persons who live in the same dwelling and eat food from a common kitchen. ${ }^{2}$ It also includes persons who are away from the village for work or other exigencies, but visited the village at least once in

\footnotetext{
1 Between 1998 and 2016, of the original sample of 891 households covered in 1998, 68 had permanently migrated from the source region - an annual rate of outmigration of $0.4 \%$, which is quite low.

${ }^{2}$ Patrilocality is the norm in rural Bihar. Daughters marry outside the household and cease to be household members post-marriage, while daughters-in-law join the household.
} 
the year preceding the survey. ${ }^{3}$ Thus, migrants are household members who share household resources when they are in the village and maintain a rural residence otherwise. ${ }^{4}$ For the purpose of this study, a migrant is defined as any individual who was away from the village for more than a month in the year preceding the survey.

The class categorisation in the paper is based on the economic system, more specifically production relations in the village. Agricultural labour households were households where one or more members worked for wages in agriculture. Peasant households cultivated land, irrespective of whether they owned the land they cultivated. Landlord households were those where member(s) were engaged, only in supervision of agriculture, and in non-agricultural households, no member(s) did agricultural work. In the context of Bihar, upper castes include: Bhumihar, Brahmin, Kayastha, and Rajput. The classification, other backward classes II, comprises several castes, among which the Kurmis, Koeris, and Yadavs-traditionally cultivating castes - are dominant. The nomenclature 'backward', in the context of 'OBC II', we will see, is a misnomer; some of the OBC II castes have socio-economic characteristics similar to those of the upper castes. OBC I, on the other hand, are at the lower end of the caste hierarchy, and their social and economic profile is inferior to OBC II and close to the scheduled castes (SCs) and scheduled tribes (STs). The SCs (Dalits) comprise erstwhile untouchable castes, who along with STs (Adivasis) are historically disadvantaged and lowest in the caste hierarchy. ${ }^{5}$

\section{Key Characteristics of Migration}

Overall, $18.8 \%$ of the individuals in the sample were migrants. In other words, almost one in five persons in rural Bihar is a migrant. Outmigration is highly masculinised $^{6}$; among all migrants, $85.2 \%$ are male. Migration streams are most maledominated among those at the bottom of the community, caste, and class spectrum: Muslims, scheduled castes and scheduled tribes, and OBC I, as well as agricultural labouring households. On the other hand, among upper castes and OBC II communities, as well as the landlord class and some peasant classes, the incidence of female migration is substantially higher than average as these households are more

\footnotetext{
3 This definition of migration is attuned to the empirical context of the study. It is also close to other empirically grounded work, such as the Indian Human Development Survey, where labour migrants are defined as, "non-resident household members who are identified through household response to: "Does any woman in the household have a husband who lives outside the household"?' (Nayyar and Kim 2016, p. 6). However, in addition to male labour migrants, our study also collected information on female migration. We are also able to identify households that permanently migrated from source areas.

4 The rural residence is maintained by sending regular remittances to their rural household; remittances were near universal-more than $90 \%$ of households with migrants received remittances. Remittance income was also the most important source of income for source households with migrant members-on an average-remittances accounted for more than half of the total income in such households.

5 The share of STs in Bihar's overall population is negligible, and therefore, the number of STs is very small in the sample.

${ }^{6}$ Less than $6 \%$ of females in the sample were migrants, compared to $31 \%$ males.
} 
Table 1 Households with migrants by district, class, and land ownership (\%)

\begin{tabular}{ll}
\hline District & \\
Araria/Purnia & 69.4 \\
Gaya & 54.9 \\
Gopalganj & 71.0 \\
Madhubani & 73.1 \\
Nalanda & 43.5 \\
Rohtas & 53.5 \\
Class & \\
Agricultural labour & 62.6 \\
Small and medium peasant & 54.9 \\
Large peasant and landlord & 63.5 \\
Non-agricultural & 71.2 \\
Landownership & \\
Landless & 66.1 \\
0.01-0.99 acres & 66.7 \\
1-2.49 acres & 57.7 \\
2.5-4.99 acres & 62.5 \\
5 acres or more & 59.1 \\
Total & 64.9 \\
\hline Source: & \\
\hline
\end{tabular}

Source: Institute for Human Development (IHD), Bihar Household Survey, 2016

likely to be able to financially support female family members at destination. ${ }^{7}$ Outmigration from rural Bihar is predominantly for work; $83.3 \%$ of all migrants and $91.2 \%$ of male migrants in the age $15-64$ are workers. ${ }^{8}$

Nearly two-thirds of the sample households have at least one migrant member (Table 1). Outmigration is higher from the relatively backward districts of north Bihar-Purnia/Araria, Gopalganj, and Madhubani, compared to the relatively better off districts of south Bihar, such as Nalanda and Rohtas. By class, as expected, migration is highest among the non-agricultural classes and lowest among small and medium peasants. The latter are more likely to own medium tracts of land, belong to the cultivating castes, predominantly OBC II, practice agriculture, and thus, have relatively lower rates of migration. On the other hand, migration is highest among the upper castes and Muslims (not shown in table).

The duration of migration varied considerably among migrants. On the whole, migration streams of up to 5 months in a year were insubstantial. (Less than $6 \%$ of total migrants reported being away from the village for a period of up to 5 months in the preceding year.) On an average, more than a third of the migrants had migrated for

\footnotetext{
7 Thus, female migration is predominantly associational $-80.9 \%$ female migrants in the age $15-64$ years are non-workers.

${ }^{8}$ Worker here refers to persons who are engaged in a primary occupation with any of the following activity status: employer, own account worker (self-employed), regular wage (salaried), casual wage labour, and unpaid family labour.
} 


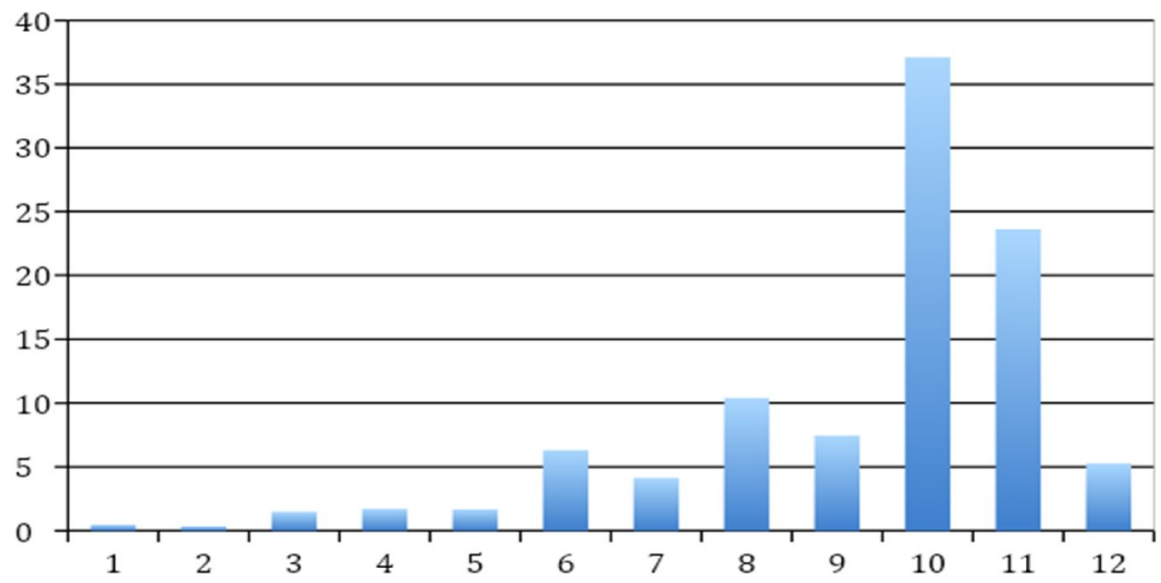

Fig. 1 Number of Months Migrated in Last 12 Months (\% migrants). Source: IHD Bihar Household Survey, 2016

10 months, and two-thirds of the migrants had migrated for 10 months or more in the year preceding the survey (Fig. 1).

In other words, an overwhelming majority of migrants migrate for long durations, and the survey data shows that they are delinked from the rural labour market. Thus, migration from rural Bihar can be termed as 'long-term' as well as 'circular', i.e., migrants migrate for long durations only to eventually return to source areas. At the same time, among migrants migrating for 0-6 months - a majority belonged to the districts of Purnia and Araria, the agricultural labouring class, landless and the SC and ST, and OBC I castes. Thus, shorter-term migration streams were dominated by migrants from the poorest regions and those at the bottom of the caste and class hierarchy- the most precarious migration streams, further elaborated in the next section.

Precarity is also reflected by educational status. While on the whole, migrants are more educated than residents, migration streams at the bottom of the education spectrum are dominated by the most vulnerable social groups and poorest source regions. For instance, the most precariously placed scheduled castes and OBC I migrants comprise nearly $70 \%$ of illiterate migrants. Similarly, three-quarters of all illiterate migrants are from the relatively poor and backward districts of Purnia/Araria and Madhubani, in north Bihar.

It is against this backdrop, the next section provides a snapshot of migrant workers at destinations - their migration locations, work, employment, income, working and living conditions, and identity documents in source and destination areas. 
Table 2 Migrant workers' destination by rural and urban areas and income from migration in the preceding year (in rupees)

\begin{tabular}{lrrl}
\hline & \multicolumn{2}{l}{ Destination } & Income from migration in the \\
\cline { 2 - 3 } & Urban & Rural & \\
\hline Class & & & \\
Agricultural Labour & 49.8 & 50.2 & 54,616 \\
Peasant & 89.2 & 10.8 & 95,079 \\
Landlord & 92.5 & 7.5 & 137,579 \\
Non-agricultural & 93.0 & 7.0 & 95,181 \\
Caste & & & \\
Upper & 94.7 & 5.3 & 107,812 \\
OBC II & 80.5 & 19.5 & 102,602 \\
OBC I & 69.2 & 30.8 & 71,640 \\
SC and ST & 57.6 & 42.4 & 67,473 \\
Muslim & 94.2 & 5.8 & 91,025 \\
Total & 76.9 & 23.1 & 85,141 \\
\hline
\end{tabular}

Source: Migration Module, IHD Bihar Survey, 2016

\section{Snapshots of Migrant Workers' Lives at Destinations}

\subsection{Destination Locations}

A significant majority-nearly four in five migrant workers from rural Biharmigrate to an urban destination (Table 2). However, disaggregation by caste and class reveals striking patterns. Rural destinations are linked with lower incomes, and in turn, precarity, and migrants from agricultural labouring classes were far more likely to go to a rural destination, as is the case for migrant workers from scheduled castes and scheduled tribes. On the other hand, migrants from upper castes, landlord, and non-agricultural classes, are more likely to be at an urban destination. ${ }^{9}$

The aforementioned disaggregated migration streams reveal that those at the lower end of the social and economic hierarchy dominated rural-rural migration streams understood to be short-term and more precarious in nature. Thus, an individual's social and economic position in the village is closely intertwined with his migration trajectory and is a function of migration outcomes at destination.

Data on the location of current migration show that more than $90 \%$ migrant workers from rural Bihar undertake long-distance migration to go to other states within India. Migration within Bihar (5.8\%) and migration outside India (2.8\%) are quite low. ${ }^{10}$ The relatively well-off states in north India are the most important destinations for Bihari migrant workers; the three states of Punjab, Delhi, and Haryana

\footnotetext{
9 Source location within Bihar mattered too. Those from the poor and backward districts of North Bihar dominated rural-rural migration streams. For instance, from Purnia and Araria, $55 \%$ and $42 \%$ migrant workers reported going to a rural destination.

10 An earlier survey in 2009 reports similar patterns of migration destinations (Rodgers et al. 2013).
} 


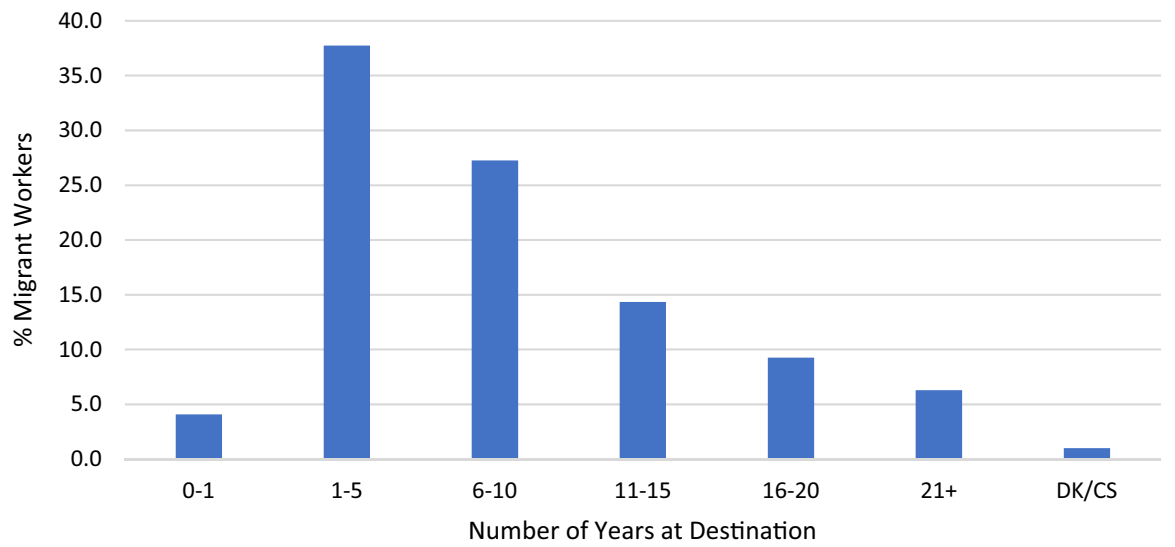

Fig. 2 Years Spent at Current Migration Destination (\% of migrant workers). Source: Migration Module, IHD Bihar Survey, 2016. Note: DK/CS = Don’t Know/ Can’t Say

account for about half of all migrant workers from Bihar. In west India, Maharashtra $(10.3 \%)$ and Gujarat $(6.1 \%)$ are important destinations. In recent years, the southern states have also emerged as important, while earlier migration streams to eastern India, particularly West Bengal have diminished (now, 2.4\%). The data also reveal certain circuits of migration: Rohtas-Gujarat; Madhubani-Delhi; Madhubani-Mumbai; Purnia/Araria-Punjab; Araria-Himachal Pradesh; Madhubani-Bangalore. These migration corridors offer a glimpse into the precarity-prosperity nexus - the demand for rural migrant labour to relatively prosperous destinations across India.

To better understand the nature of linkages with destination areas, information was collected on how long a migrant worker had been regularly working at their current destination. More than half of all migrants had been staying at their current destination for more than six years, and herein, more than $15 \%$ of all migrants had stayed at their current destination for 16 years or more (Fig. 2). Thus, it is clear that a majority of migrants have long-term linkages with their destination and have welldefined migration trajectories to long-standing destinations.

\subsection{Work}

\subsubsection{Work status}

Migrant workers from rural Bihar were most likely to be casual wage labourers $(50.3 \%)$, followed by regular wage/salaried in the private $\operatorname{sector}^{11}(33.8 \%)$. A minority of workers were self-employed (6.5\%), regular wage/salaried in the public sector $(4.4 \%)$, in piece-rate or contractual work $(4.2 \%)$, and unpaid family labourers $(0.8 \%)$. There were clear class and caste patterns of precarity in the

\footnotetext{
11 Regular wage/salaried employment here does not imply working in the organised sector. It refers to a job where there stability and a fair certainty about continuity of work.
} 
Table 3 Work status of migrant workers by class (\%)

\begin{tabular}{llllll}
\hline & $\begin{array}{l}\text { Agri- } \\
\text { cultural } \\
\text { labour }\end{array}$ & Peasant & Landlord & Non-agricultural & Total \\
\hline Own account worker (self-employed) & 15.3 & 45.8 & 10.2 & 28.8 & 100.0 \\
Regular wage private (salaried) & 14.7 & 21.6 & 16.7 & 47.1 & 100.0 \\
Regular wage govt (salaried) & 5.0 & 37.5 & 35.0 & 22.5 & 100.0 \\
Casual wage labour & 54.4 & 12.7 & 3.9 & 28.9 & 100.0 \\
Piece rate/contractual & 39.5 & 18.4 & 7.9 & 34.2 & 100.0 \\
Unpaid family labour & 28.6 & 42.9 & 14.3 & 14.3 & 100.0 \\
Total & 35.4 & 19.4 & 10.3 & 34.9 & 100.0 \\
\hline
\end{tabular}

Source: Migration Module, IHD Bihar Survey, 2016

Table 4 Distribution of primary occupation for of migrant workers $(\%)$

\begin{tabular}{lc}
\hline Occupation & $\begin{array}{c}\text { \% Migrant } \\
\text { workers }\end{array}$ \\
\hline Agriculture and animal husbandry & 21.8 \\
Mason, welder, repair mechanic, electrician & 5.5 \\
Driver, conductor & 2.4 \\
Construction and brick-making & 23.5 \\
Hotel, dhaba, restaurant, tea stall & 4.0 \\
Textile and handloom & 5.6 \\
Tailoring & 3.9 \\
Sales and kirana store & 2.4 \\
Administrative, professional, and technical services & 0.8 \\
Security workers & 4.1 \\
Other manufacturing, small household industry & 3.8 \\
Others* & 22.1 \\
Total & 100.0 \\
\hline
\end{tabular}

Source: Migration Module, IHD Bihar Survey, 2016

*The 'Others' category include: fisheries, mining and quarrying, trading, lawyer, quack, traditional artisans, caste occupations such as brahmin and nai, tutor, political representatives, hairstylist, janitor, painter, carpenter, plumber, etc.

work status of migrant workers. Migrant workers in the agricultural labouring class (Table 3) and scheduled castes and scheduled tribes and OBC I communities were more likely to be in casual wage employment (table not shown). On the other hand, those from the landlord class were disproportionately represented in salaried employment and even more so in public employment-the most secure 
kind of employment (Table 3). In a similar vein, the upper and OBC II castes were more likely to be in regular wage employment.

\subsubsection{Occupation}

About a fifth of all migrant workers were employed in the agricultural sector (Table 4). The remaining workers - a substantial majority-worked in diverse nonagricultural occupations. Among these, construction and brick-making were predominant, followed by a variety of non-agricultural occupations, both, in the services and manufacturing, predominantly in prosperous urban destinations.

Again, clear class and caste patterns were evident in the occupational profile of migrant workers. Those at the bottom of the social and economic hierarchy were most likely to work in agriculture and allied occupations, characterised by harsh working conditions and low incomes. For instance, among migrants who worked in agriculture and allied activities at destination, nearly $85 \%$ belonged to the agricultural labouring class. By caste, more than three-quarters of workers employed in agriculture and allied activities belonged to SC and ST communities or OBC I castes. Similarly, nearly two-thirds of migrant workers in construction and brickmaking belonged to SC and ST and OBC I castes. On the other hand, security workers, who were relatively better off, were most likely to belong to the upper castes. A miniscule of migrants worked in administrative, professional, and technical services; albeit the small numbers, these professions were dominated by the upper and OBC II castes.

\subsubsection{Employment contract}

Nearly $80 \%$ of migrant wage workers had verbal/oral employment contracts. Verbal contracts commonly persist in the informal economy; they are the norm, not only for casual employment, but also for more secure forms of employment, such as longterm jobs that are remunerated on a monthly basis. There were high variations in the type of employment contract by social group. Individuals from upper castes and OBC II, the landlord class, and the districts of southern Bihar were far more likely to have a written employment contract. On the other hand, individuals in OBC I and SC/ST castes, agricultural labouring classes, and the districts of Purnia and Araria were more likely to have oral employment contracts, which are hard to enforce, legally, and thus tilted against the worker in case of a dispute. Patterns of precarity are evident when we look at nature of employment contract within activity groups. Casual labourers are the most precarious (92.3\% had oral contracts) followed by regular wage in the private sector ( $66.7 \%$ with oral contracts). ${ }^{12}$ Oral contracts abdicate the employer from the responsibility to protect workers, and the current migration crisis bears testimony to the fact that despite being employed in relatively stable jobs, migrant workers are highly vulnerable in times of economic shock, such as

\footnotetext{
12 Regular wage workers in the government sector were least precarious; only $2.5 \%$ workers had oral contracts. The remaining $97.5 \%$ workers had written contracts.
} 


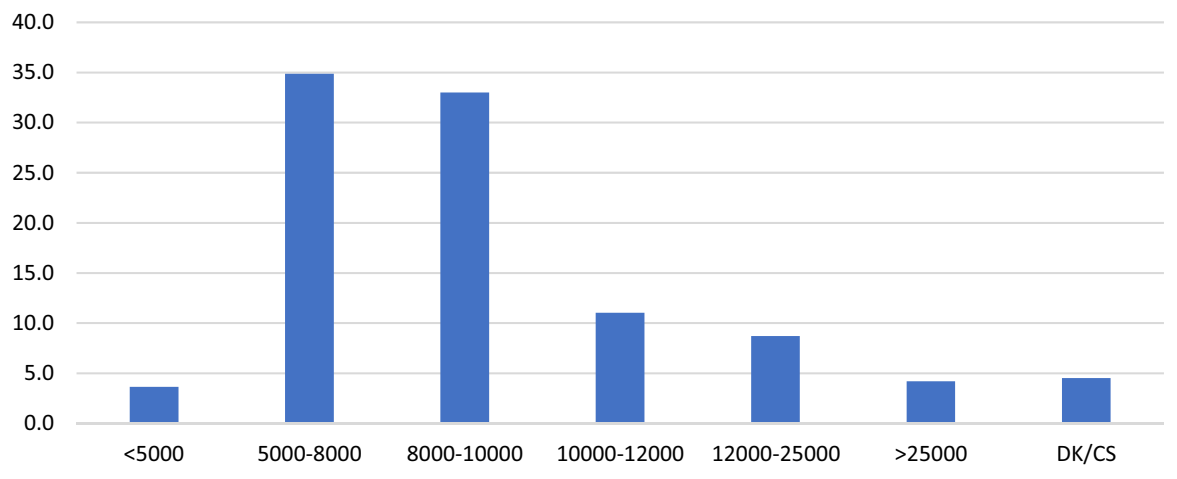

Fig. 3 Income earned in the last month, in rupees (\% migrants). Source: IHD Bihar Survey, Migration Module 2016. Note: DK/CS = Don't Know/ Can't Say

the one created by the pandemic and subsequently amplified by the sudden stateimposed lockdown.

\subsubsection{Working hours and days worked in a month}

On an average, migrant workers were engaged in work for about $9.5 \mathrm{~h}$ every day; more than $80 \%$ of the workers reported working for 8-10 h in a day. An additional $14 \%$ worked 11-12 h every day. There was little variation in mean working hours by social group; however, among the relatively small proportion of migrant workers who worked more than $12 \mathrm{~h}$ a day, SC and ST communities, as well as migrants from the labouring classes, were disproportionately represented. Again, agriculture and construction, as well as the textile and handloom sector, stood out as most precarious sectors in which migrants worked longer hours than average.

The survey shows, that, on an average, migrant workers worked for 26 days in a month. However, 23\% of the sample of migrant workers worked for 30 days in a month. In other words, nearly a quarter of all migrant workers did not have a weekly off at destination. Thus, the working conditions of Bihari migrants vary considerably in destination areas. However, again, those at the bottom of the social and economic hierarchy (agricultural labour class, SC, and ST), are more likely to be employed in casual work at destination, disproportionately reported working without a weekly off.

\subsection{Income from Migration}

The median income of migrant workers at destination in the month preceding the survey was Rs. 9000. It can be seen in Fig. 3 nearly $40 \%$ migrant workers had earned less than 8000 rupees in the previous month. Thus, while migration at destination may offer regular, full-time work, its remuneration, for a majority of 
workers, is low-it is below the statutory minimum wage in many destination areas. Low incomes disable migrant workers from bringing their families to destination areas, and in the long run destination areas do not offer them the possibility to settle down or retire.

Class and caste patterns persist in income from migration. Migrant workers at the lowest end of the income spectrum - those who report less than 5000 rupees income in the month preceding the survey-were dominated by the SC and ST and OBC I household and the agricultural labour class. Survey results show that the upper castes earned the highest income in the month preceding the survey, followed by the OBC II, Muslim, OBC I, and SC and ST migrants. Similar findings have emerged from destination area research in slums, where Chandrasekhar and Mitra (2019) find that upper caste migrants have higher earnings.

\subsection{Living Conditions}

Migrant workers lived in harsh conditions at destination. More than $90 \%$ lived in rented or employer provided housing ${ }^{13}$; home ownership at destination was rare (1.3\%). Housing conditions were cramped; on an average, a migrant shared accommodation with three other persons. Typically, there was no separate kitchen; a majority of workers cooked in the same space where they lived. ${ }^{14}$ It was less common to cook outside the house $(5.6 \%)$ or not cook at all (4.1\%). Nearly, $19 \%$ migrants resorted to open defecation, and open defecation rates were substantially higher in precarious migration streams such as those from Purnia and Araria, among SCs and STs and among the labouring classes. Access to drinking water through borewells $(34.1 \%)$ or piped municipal supply $(32.3 \%)$ was mostly constrained and contingent upon landlords, who decided and controlled how much water migrant workers could get, and when. ${ }^{15}$

\subsection{Identity Documents in Source and Destination}

Documents issued by the government are an important aspect of an individual's domicile, the place to which he or she belongs, and are linked with entitlements and access to welfare schemes. Despite having worked and lived at destination for a long time, a miniscule proportion of migrants had any identity documents such as ration card $(0.7 \%)$, voter ID card (1.3\%), Aadhar card (3.3\%), PAN Card (1.1\%), or even a bank account $(10.0 \%)$ at destination. The lack of identity (documents) at destination can make migrants particularly vulnerable at times of crisis, such as the current one, and migrants thus sought recourse to their villages where their household was

\footnotetext{
13 The latter was common for agricultural and construction workers.

14 Nearly two-thirds migrant workers reported this arrangement, and only a minority of migrants (20.4\%) reported having a separate kitchen. As expected, such migrants were more likely to be from upper caste, landlord, and large peasant households.

15 Other sources of water were tankers $(13.5 \%)$ and outright purchase of water $(3.3 \%)$, both quite expensive, and handpumps (10\%) which were laborious to use.
} 
located, as there was a sense of permanence attached, with the source region, while the destination, albeit, being the place where the migrant workers lived, had little meaning attached to their identity.

A small proportion of migrants had Aadhar cards issued at destination, a relatively recent phenomenon. Most migrant workers do not participate in political activities such as elections at destination, as their identities were attached to their source villages in rural Bihar. At the same time, as noted by Roy (2016) a majority of migrant workers are unable to go back to their villages to vote, and thus, they remain political disenfranchised in both source and destination regions. There is also a clear caste and class pattern in the ownership of identity documents. Migrants at the bottom of the economic and social hierarchy were least likely to have these documents at destination, ${ }^{16}$ and in turn, the weakest foothold at destination locations.

\section{Conclusion}

Based on an empirical study, this paper emphasised elements of precarity in migration streams from rural Bihar. A majority of migrants were employed in prosperous urban regions across India, but worked in precarious conditions in the informal economy, with little job security. Incomes from migration were low, and despite having worked and lived in the destination for long periods, migration did not offer the possibility to bring family members or settle down in destination areas neither could migrant workers claim any attachment to destination regions by way of access to entitlements as their identity documents were linked to source regions. While the vast majority of migrant workers lived a precarious existence in destination, those at the lowest rungs of the social and economic ladder in source regions- the scheduled castes and scheduled tribes, other backward classes I and the labouring classwere the worst off. They were part of the most precarious shorter-term migration streams, earned the lowest incomes, had the poorest conditions of work, and lived in the harshest conditions compared to others. Thus, an individual's vulnerable social and economic position in the village was closely intertwined with his migration trajectory and outcomes at destination. As shown in the course of the paper, precarity in source region was reproduced at destination, and there was little evidence that spatial mobility was a precursor to social mobility.

There are several implications for policy that emerge from this study. First, it is evident that data and information constraints on mobility severely limited policymaking at a crucial juncture as the state was simply not able to fathom the extent of migration that exists in India. Thus, the statistical system needs to collect adequate and reliable data to capture the extent of diverse migration streams, not only to better anticipate and manage crises, but also to better understand its linkages with and contributions to development in destination regions. Second, to address low earnings and income - the precarity of migrant workers - a living wage, that is able to

\footnotetext{
${ }^{16}$ For instance, only $3.8 \%$ of SC and ST migrant workers reported bank accounts at destination, compared to nearly $23.8 \%$ of upper caste migrant workers.
} 
provide a decent standard of living to migrant workers and their families at destination should be legislated, along with the provision of universal social security. Had these two social policy interventions been in place, the mass exodus of workers and the unprecedented crisis of migration that emerged as a result of the government lockdown and subsequent economic shock of COVID 19 could have been averted. Third, despite evidence of some southern states—especially Kerala-having been relatively hospitable to migrant workers during the pandemic, structural issues such as exclusion of migrant workers from local trade unions (Prasad-Aleyamma 2017) and their social isolation and criminalisation at destination remain (Jeyaranjan 2017b). Thus, public policies need to address the intersecting precarities in migrant workers' economic and social lives at destination to better manage the current crisis of migration.

Acknowledgements I am thankful to the Indian Council of Social Science Research for funding this research, to Vikas Dubey for database management of the research project, and to the editors of this Special Issue for their thoughtful comments. Any errors remain solely mine.

\section{Appendix}

See Tables 5 and 6.

Table 5 Distribution of sample households by class

Table 6 Distribution of sample migrant workers by class

\begin{tabular}{lcc}
\hline Class & $\begin{array}{l}\text { Number of house- } \\
\text { holds }\end{array}$ & Percentage \\
\hline Agricultural labour & 534 & 33.6 \\
Peasant & 400 & 25.2 \\
Landlord & 149 & 9.4 \\
Non-agricultural & 505 & 31.8 \\
Total & 1588 & 100.0 \\
\hline
\end{tabular}

Source: IHD Bihar Survey 2016

\begin{tabular}{lll}
\hline Class & $\begin{array}{l}\text { Number of migrant } \\
\text { workers }\end{array}$ & Percentage \\
\hline Agricultural labour & 321 & 35.4 \\
Peasant & 176 & 19.4 \\
Landlord & 93 & 10.3 \\
Non-agricultural & 316 & 34.9 \\
Total & 906 & 100 \\
\hline
\end{tabular}

Source: IHD Bihar Survey, Migration Module 2016 


\section{References}

Anh, N.T., J. Rigg, L.T.T. Huong, and D.T. Dieu. 2012. Becoming and being urban in Hanoi: Ruralurban migration and relations in Viet Nam. Journal of Peasant Studies 39(5): 1103-1131.

Breman, J. 2019. Capitalism, inequality and labour in India. Cambridge: Cambridge University Press.

Breman, J., I. Guérin, and A. Prakash. 2009. India's unfree workforce of bondage old and new. New Delhi: Oxford University Press.

Breman, J. 2009. The great transformation in the setting of Asia. Public lecture to accept honorary doctorate. The Hague: International Institute of Social Studies.

Breman, J. 1996. Footloose labour: Working in India's informal economy. Cambridge: Cambridge University Press.

Census of India. 2001. Census of India. New Delhi: Government of India, Office of the Registrar General and Census Commissioner.

Chandrasekhar, S., and A. Mitra. 2019. Migration, caste and livelihood: Evidence from Indian cityslums. Urban Research and Practice 12(2): 156-172.

Chen, C., and C.C. Fan. 2018. Rural-urban circularity in China: Analysis of longitudinal surveys in Anhui, 1980-2009. Geoforum 93: 97-104.

Collinson, M., S.M. Tollman, K. Kahn, S. Clark, and M. Garenne. 2006. Highly prevalent circular migration: Households, mobility and economic status in rural South Africa. In African Migration in Comparative Perspective, ed. S.M.T.M. Tienda, E. Preston-Whyte, and S.E. Findlay, 194-216. Johannesburg: University of the Witswatersrand Press.

Das, B., and G.B. Sahu. 2019. Coping with cities and connecting with villages: Migrant workers in Surat city. Indian Journal of Labour Economics 62(1): 89-112.

Datta, A. 2018. Pride and shame in the city: Young people's experiences of rural-urban migration in India. Children's Geographies 16(6): 654-665.

Datta, A. 2016. Migration, remittances and changing sources of income in rural Bihar (1999-2011). Economic and Political Weekly 51(31): 85-93.

Datta, A., G. Rodgers, J. Rodgers, and B.K.N. Singh. 2014. Contrasts in development in Bihar: A tale of two villages. Journal of Development Studies 50(9): 1197-1208.

Deshingkar, P., and J. Farrington. 2009. Circular migration and multi-locational livelihood strategies in rural India. New Delhi: Oxford University Press.

Ellis, F. 1998. Household strategies and rural livelihood diversification. Journal of Development Studies 35(1): 1-38.

Fan, C.C. 2008. China on the move: Migration, the state, and the household. London: Routledge.

GOI-Government of India. 2010. Migration in India 2007-2008, NSS Report no. 533. New Delhi: Government of India, National Sample Survey Office, Ministry of Statistics and Programme Implementation. Available at: https://mospi.nic.in/sites/default/files/publication_reports/533_ final.pdf.

Hirway, I., and U.B. Singh. 2017. Migration and development: Rural-to-urban temporary migration to Gujarat. In Rural labour mobility in times of structural Transformation, ed. D.N. Reddy and K. Sarap, 269-297. Singapore: Palgrave Macmillan.

Hugo, G.J. 1982. Circular migration in Indonesia. Population and Development Review 8: 59-83.

Jain, P., and A. Sharma. 2019. Super-exploitation of Adivasi migrant workers: The political economy of migration from southern Rajasthan to Gujarat. Journal of Interdisciplinary Economics 31(1): 63-99.

Jeyaranjan, J. 2017a. The life and times of migrant workers in Chennai. In Rural labour mobility in times of structural transformation, ed. D.N. Reddy and K. Sarap, 299-326. Singapore: Palgrave Macmillan.

Jeyaranjan, J. 2017b. Migration and development: Rural-to-urban temporary migration to Gujarat. In Rural labour mobility in times of structural transformation, ed. D.N. Reddy and K. Sarap, 299-326. Singapore: Palgrave Macmillan.

IHD_Institute for Human Development. 2018. Political Economy of Development, Poverty and Change in Rural Bihar. Report submitted to the Indian Council of Social Science Research. New Delhi: Institute for Human Development.

Iyer, S. 2017. Circular migration and localized urbanization in rural India. Environment and Urbanization ASIA 8(1): 105-119. 
Lerche, J., and A. Shah. 2018. Conjugated oppression within contemporary capitalism: Class, caste, tribe and agrarian change in India. Journal of Peasant Studies 45(5-6): 927-949.

Mander, H., I. Roy, P. Jain, R. Raman, R.G. Ray, A. Bhattacharya, \& U.J. Siddiqi. 2019. Stolen citizenship, stolen freedoms. Locating the rights of India's circular labour migrants. Esclavages \& Post-esclavages. Slaveries \& Post-Slaveries. https://doi.org/10.4000/slaveries.602.

Mosse, D., Gupta, S., Mehta, M., Shah, V., Rees, J. F., \& Team, K. P. 2002. Brokered livelihoods: Debt, labour migration and development in tribal western India. Journal of Development Studies 38(5): 59-88.

Murphy, R. 2002. How migrant labor is changing rural China. Cambridge: Cambridge University Press.

Nadkarni, M.V. 2018. Crisis in Indian agriculture: Can it be overcome? Economic and Political Weekly 53(17): 28-34.

Nayyar, G., \& K.Y. Kim 2018. India's Internal Labor Migration Paradox: The Statistical and the Real, Policy Research Working Paper No. 8356. Washington, D.C.: World Bank.

Parida, J.K., M.E. John, and J. Sunny. 2020. Construction labour migrants and wage inequality in Kerala. Journal of Social and Economic Development. https://doi.org/10.1007/s40847-020-00104-2.

Pattenden, J. 2012. Migrating between rural Raichur and boomtown Bangalore: Class relations and the circulation of labour in South India. Global Labour Journal 3(1): 163-190.

Picherit, D. 2012. Migrant labourers' struggles between village and urban migration sites: Labour standards, rural development and politics in south India. Global Labour Journal 3(1): 143-162.

Potts, D. 2010. Circular migration in Zimbabwe and contemporary sub-Saharan Africa. Oxford: James Currey.

Prasad, P.H., G.B. Rodgers, S. Gupta, A.N. Sharma, and B. Sharma. 1988. The dynamics of employment and poverty in Bihar. Patna: A.N. Sinha Institute of Social Studies.

Prasad-Aleyamma, M. 2017. The cultural politics of wages: Ethnography of construction work in Kochi, India. Contributions to Indian Sociology 51(2): 163-193.

Rai, P. 2018. The labor of social change: Seasonal labor migration and social change in rural western India. Geoforum 92: 171-180.

Rigg, J. 2007a. An everyday geography of the Global South. Oxon: Routledge.

Rigg, J. 2007b. moving lives and livelihoods in the Lao PDR. Population, Space and Place 13(3): $163-178$.

Rodgers, G., S.K. Mishra, and A.N. Sharma. 2016. Four decades of village studies and surveys in Bihar. In Himanshu, ed. P.H. Jha and G. Rodgers. Changing Village in India. New Delhi: Oxford University Press.

Rodgers, G., A. Datta, J. Rodgers, S.K. Mishra, and A.N. Sharma. 2013. The challenge of inclusive development in rural Bihar. New Delhi: Institute for Human Development and Manak Publications.

Rogaly, B., and D. Coppard. 2003. They used to go to eat, now they go to earn: the changing meanings of seasonal migration from Puruliya District in West Bengal, India. Journal of Agrarian Change 3(3): 395-433.

Rogaly, B. 2009. Spaces of work and everyday life: Labour geographies and the agency of unorganised temporary migrant workers. Geography Compass 3(6): 1975-1987.

Roy, I. 2016. Labour migration from (and in) Bihar: Continuities and change. IGC Working Paper. Oxford: University of Oxford.

Roy, I. 2014. Reserve labor, unreserved politics: Dignified encroachments under India's national rural employment guarantee act. Journal of Peasant Studies 41(4): 517-545.

Sahu, B.K. 2017. Migration and household labor use for adopting climatic stress: A study of droughtaffected areas in Odisha. In Rural labour mobility in times of structural Transformation, ed. D.N. Reddy and K. Sarap, 237-268. Singapore: Palgrave Macmillan.

Samaddar, R. 2016. Migrant and the neo-liberal city: An introduction. Economic and Political Weekly 51(26): 52-54.

Shah, A., and J. Lerche. 2020. Migration and the invisible economies of care: Production, social reproduction and seasonal migrant labour in India. Transactions of the Institute of British Geographers. https://doi.org/10.1111/tran.12401.

Sharma, A.N. 2005. Agrarian relations and socio-economic change in Bihar. Economic and Political Weekly 40(10): 960-972. 
Srivastava, R. 2020.Vulnerable internal migrants in india and portability of social security and entitlements. WP 02/2020 Centre for Employment Studies Working Paper Series. New Delhi: Institute for Human Development.

Srivastava, R. 2019. Emerging dynamics of labour market inequality in India: Migration, informality, segmentation and social discrimination. Indian Journal of Labour Economics 62(2): 147-171.

Srivastava, R. \& A.K. Jha 2016. Capital and labour standards in the organised construction industry in India: A study based on fieldwork in the National Capital Region of Delhi, Second Report for the ESRC Project on Labour Conditions and the Working Poor in India and China.

Stark, O., and R.E.B. Lucas. 1988. Migration, remittances, and the family. Economic Development and Cultural Change 36(3): 465-481.

SWAN-Stranded Workers Action Network. 2020. 21 Days and Counting: COVID-19 Lockdown, Migrant Workers, and the Inadequacy of Welfare Measures in India.

Vijay, G. 2005. Migration, vulnerability and insecurity in new industrial labour markets. Economic and Political Weekly 40(22): 163-193.

Vijayabaskar, M., S. Narayanan, and S. Srinivasan. 2018. Agricultural revival and reaping the youth dividend. Economic and Political Weekly 53(26-27): 8-16.

World Bank. 2007. World Development Report 2008: Agriculture for Development. Washington DC: World Bank.

Publisher's Note Springer Nature remains neutral with regard to jurisdictional claims in published maps and institutional affiliations. 